\title{
DEL LATÍN VULGAR AL LATÍN CLÁSICO
}

\author{
Henry Campos Vargas
}

\section{(c) $($ ) $(9)$}

Esta obra está bajo una licencia Creative Commons

Reconocimiento-No Comercial-Sin Obra Derivada 



\title{
DEL LATÍN VULGAR AL LATÍN CLÁSICO
}

\author{
FROM VULGAR LATIN TO CLASSIC LATIN
}

Henry Campos Vargas

A mi hermano Alexánder

\section{RESUMEN}

Este artículo procura explicar qué es el latín vulgar e identificar algunos de sus aportes al conocido latín clásico.

Palabras clave: latín vulgar, latín clásico, Roma, lenguas romances, evolución lingüística.

\section{ABSTRACT}

This paper explains what Vulgar Latin is and shows some contributions of the Vulgar Latin to the known Classical Latin.

Key words: Vulgar Latin, Classical Latin, Romance Languages, linguistic evolution, Rome.

\section{1. ¿Qué es el latín vulgar?}

Sobre el concepto latín vulgar Veikko Väänänen apunta:

El término latín vulgar, consagrado por un uso centenario para designar los diversos fenómenos latinos
que no están de acuerdo con las normas clásicas, tiene las ventajas y los inconvenientes de todo término
consagrado. De hecho, ha sido atacado más de una vez, sobre todo entre los latinistas. Hacen notar estos
que el epíteto "vulgar" se presta a equívocos, porque evoca demasiado exclusivamente el habla inculta, y
los más intransigentes de ellos condenan la expresión "latín vulgar" como una tosca abstracción que no

M.L. Henry Campos Vargas. Universidad de Costa Rica. Escuela de Filología y Lingüística. Costa Rica. Correo electrónico: hcamposv@yahoo.es

Recepción: 22- 10- 2014

Aceptación: 13- 11- 2014 


\begin{abstract}
corresponde en modo alguno a la realidad lingüística. Y querrían reemplazarla por términos más precisos: latín popular, latín familiar o latín cotidiano, que estarían más de acuerdo con el punto de vista social o sincrónico; romance común o protorromance, que situarían los fenómenos no clásicos en una perspectiva histórica, como base de las lenguas romances. Otros, por fin, se resignan a conservar el término consagrado, útil al fin y al cabo, aun deplorando su impropiedad y su imprecisión. (Väänänen, 1967, pp. 25-26)
\end{abstract}

En igual sentido se expresa don Manuel Antonio Quirós, para quien

El término de "latín vulgar", aunque deje mucho que desear por las implicaciones interpretativas que le son inherentes, ha sido el de mayor arraigo en los estudios de filología latina y de filología románica y no puede ser fácilmente extirpado (Quirós-Rodríguez, 2003, p. 40).

Para este autor, quien sigue a Manuel Díaz y Díaz, se trata de un calco de la frase sermo uulgaris ciceroniano.

Con este sintagma ocurre lo mismo que con muchísimos conceptos: se puede hablar de él y emplearlo, pero cuando se pregunta sobre su significado hay serias dificultades para precisarlo.

Este problema de opacidad es difícil de superar. Por ejemplo, de acuerdo con József Herman, el latín clásico es solo una de las variantes del latín. Frente a esta, una de ellas se erige como fuente común de las lenguas románicas, conocida como latín vulgar.

Para este connotado investigador, el latín vulgar identifica "[...] el conjunto de innovaciones y tendencias evolutivas aparecidas en el uso -sobre todo oral- de las capas latinófonas no influidas o poco influidas por la enseñanza escolar y los modelos literarios" (Herman, 2001, p. 14).

A pesar de las posibles virtudes de esta definición, su enfoque es muy limitado, máxime si se parte de que la literatura latina escrita tiene su aparición hacia el siglo III a.C. Esto conlleva que el concepto propuesto por Herman no puede extenderse más allá de esta época; además de que desmerece la posible existencia de puntos de coincidencia y contacto entre las variantes del latín clásico y el vulgar.

En un sentido semejante se expresa Veikko Väänänen, quien considera que el latín vulgar

[...] comprende los estados sucesivos desde la fijación del latín común, al terminar el período arcaico, hasta la víspera de la consignación por escrito de textos en lengua romance; no se excluyen, pues, ni las variaciones sociales ni aun las regionales. (Väänänen, 1967, p. 29)

Estos períodos comprenden los siguientes:

a. Latín arcaico, desde los orígenes de Roma hasta fines del siglo II a. C.

b. Latín preclásico, desde finales del siglo II a. C. a la primera mitad del siglo I a. C.

c. Latín clásico, o "Edad de oro" que comprende desde la segunda mitad del siglo I a. C. a la muerte de Augusto, acaecida en el 14 d. C.

d. Latín postclásico, conocido como "Edad de plata", desde la muerte de Augusto hasta el 200 d. C.

e. Latín tardío o bajo latín, desde el 200 d. C. hasta la llegada de las lenguas romances. Por su parte, don Manuel Antonio Quirós considera que

El latín vulgar era la lengua hablada por todas las clases sociales de la Urbs y por la gente que había sido conquistada en donde estuviera expandido el Imperio Romano. El registro de tal latín era mucho menos unitario y homogéneo que el del latín clásico, el de los grandes escritores romanos: los de primera clase, de donde las divergencias y particularidades diastráticas y diatópicas del latín vulgar; incluso, romanos cultos de la talla de un Cicerón tenían conciencia de que el sermo vulgaris no se regía por los mismos cánones normativos del sermo urbanus. (Quirós-Rodríguez, 2000, p. 34) 
Ahora bien, a diferencia de los autores citados anteriormente, en este artículo se considera que el latín vulgar existió incluso en el período arcaico. Durante esta etapa de la evolución del latín, fue este el que moldeó muchas de las particularidades del que sería el latín posterior. ¿A qué otra fuerza, sino al uso lingüístico de los hablantes, puede atribuirse el proceso de regularización de una lengua en "formación"? ¿Qué otro motor generaría su transformación?

En este sentido, siguiendo a Quirós-Rodríguez

[...] así puedo afirmar, según mi leal saber y entender, que el latín vulgar no es otra cosa que el idioma de la vida diaria en contraposición con el otro subcódigo: el usado, casi siempre, en la escritura, y principalmente, en las obras literarias. (2003, p. 42)

Dicha compleja realidad lingüística ha sido denominada de distintas formas, así

Sermo familiaris, sermo militaris, sermo piscatorius, sermo plebeius, sermo proletarius, sermo quotidianus (Quintiliano), sermo ruralis, rusticus $<$ rus, ruris, campos ciudad, uerba cotidiana (Cicerón). (Quirós-Rodríguez, 2003, p. 40)

Por su parte, en español existen las denominaciones

latín vulgar, latín hablado, latín popular, latín familiar. Y en relación con las futuras variedades romances, estos nombres: prerromance, prerrománico, protorromance, términos que indican un estado precedente a ellas. (Quirós-Rodríguez, 2003, p. 40)

Este latín era una variante de la lengua asociada a su práctica verbal, que coexistió junto al propio latín arcaico.

[Este] latín oral comenzó a ser empleado como subcódigo escrito en documentos epigráficos, el primero de los cuales es la Fibula de Preneste, principios del VI [...] A partir de los documentos arcaicos, la evolución es lenta hacia la consolidación de un sistema estructural, al cual se le implanta la razón, base de toda lengua escrita estructuralmente bien consolidada. (Quirós-Rodríguez, 2003, p. 46)

El latín vulgar corresponde, etimológicamente, al latín del vulgo, es decir, del pueblo, la plebe, la masa de gente. Sin embargo, el vulgo no es necesariamente una categoría políticoeconómica, como correspondería con el vocablo plebe. El vulgo es el pueblo lato sensu.

Esta variante del latín es el equivalente lingüístico de los soles respecto de la materia que hay en el universo. Es el motor en el que se genera, se crea, se transforma y vive la lengua, en este caso, el latín.

El latín vulgar y el clásico interactúan entre sí a lo largo del tiempo en diversos campos, pero principalmente en:
a. la lengua
b. la literatura

En literatura, el latín vulgar marca una impronta ya que aparece registrado en numerosos textos clásicos, ámbito en el que parece haber constituido una especie de código, de marca de legitimación literaria que habría sido inaugurada por los primeros iniciadores de la literatura romana, en particular, Livio Andrónico, Gneo Nevio y Ennio, quienes registran en su obra numerosas apariciones del latín vulgar de su época.

A partir de ellos, sus continuadores literarios consideraron esta como una práctica legítima e, incluso, necesaria, en sus creaciones. Por esto, no es de extrañar que Cicerón, Virgilio, Horacio, Ovidio... consignen gran cantidad de vocablos que asociamos a este registro en sus textos. 
Considérese por ejemplo el Carmen I de Catulo:

Quoi dōnō lepidum nouum libellum

$\bar{A}$ ridā modō pūmice expolītum?

Cornēlì, tib̄̄; namque tū solēbās

Meās esse aliquid putāre nūgās,

Iam tum cum ausus es ūnus Italōrum

Omne aeuum tribus explicāre cartīs

Doctīs, Iuppiter, et labōriōsis.

Quārē habē tib̄̄ quicquid hoc libellī,

Quālecumque; quod, ō patrōna uirgō,

Plus ūnō maneat peremne saeclō.

(Valerio, 2012, p. 1)

¿A quién regalo este nuevo y exquisito librito

de su aridez, recién, con pómez, pulido?

¡Oh! Cornelio, a ti, pues tú solías

considerar que algo eran mis juegos,

desde la ocasión en que osaste, único entre los ítalos,

toda la historia en tres libros exponer,

doctos, ipor Júpiter!, y laboriosos.

Por esto, conserva para ti esta nonada de librito,

cualquierura; que, ¡oh! Virgen protectora,

peremne permanezca por más de un siglo

(la traducción es del autor).

Esta hermosa composición en versos faleucos, de notorios rasgos epistolográficos, presenta muchas características relevantes para el estudioso de la literatura latina y de esta lengua. Para este último grupo, destaca el uso de un exquisito latín clásico que coexiste con formas arcaicas $(q u o i>c u \bar{\imath})$ y vulgares $($ saeclō<saeculō). Cabe destacar precisamente la ubicación de estas voces, al inicio y al final del poema, lo que no parece casual.

La dedicatoria está dirigida a Cornelio Nepote, historiador romano. Esto es particularmente importante, pues nada obsta para que un hombre de letras como él, descubra en esta dedicatoria estos dos registros. ¿Cómo era esto posible, máxime cuando el mismo Catulo declara haber pulido su libro con piedra pómez?

Una explicación podría encontrarse en la existencia de ciertos códigos literarios entre los escritores latinos. Tales códigos no solo permitirían sino que exigirían, por un principio estético, el empleo de este tipo de voces; ya que se trataba de una especie de carta de presentación y legitimación del escritor.

En efecto, se trata de una práctica intencional, posiblemente fundada, a la vez que legitimada, en una larga tradición literaria, cimentada en la autoridad de los grandes escritores de la antigüedad romana.

Conviene destacar en este sentido, que en el mismo poemario catuliano aparece la forma completa de aquel uso vulgar. Se trata del poema XCV: 


\title{
Zmyrna cauās SatrachIl penitus mittētur ad undās,
}

Zmyrnam cāna dīu saecula peruolent.

Se enviará, dentro, a las huecas ondas del Satraco la Esmirna,

volverán la Esmirna, largo, los canos siglos (2012, 82, 5,6).

Frente a esta única aparición sin modificaciones morfológicas, la forma sincopada saeclum tiene lugar en distintos poemas saeclī (XIV, 23, 2012, p. 10), saeclum (XLIII, 8, 2012, p. 26), saeclōrum (LXIV, 22, 2012, p. 49), saeclīs (LXVIIIb, 43, 2012, p. 69), saecla (LXXVIIIb, 9, 2012, p. 77).

Entre otros fenómenos vulgares presentes en Catulo destaca sobremanera la aglutinación en formas como molestumst< molestum est (LV, 1, 2012, p. 32) y dolorist<doloris est (XCVI, 5, 2012, p. 83).

\section{El latín vulgar como fuente del latín clásico}

Los aportes del latín vulgar al latín clásico son considerables (sobre el tema puede consultarse Campos 2010, p. 127). Piénsese, por ejemplo, en estas dos palabras del latín que se considera clásico: opus y opera. De acuerdo con Segura-Munguía la primera acepción de estas palabras son las siguientes:

\footnotetext{
opus, operis, $n$. , obra, trabajo, labor (2003, p. 519)

opera, -ae, $f$. , trabajo, labor, actividad (2003, p. 517)
}

Tal y como se aprecia, sus campos semánticos son idénticos y sus significados son prácticamente los mismos. Empero, el segundo deriva del primero. En efecto, en el plural neutro opera el vulgo identificó una palabra femenina de la primera declinación, merced a su terminación en - $a$ breve, y la regularizó. Con el pasar del tiempo, este neologismo se incorporó al uso general del latín y se gramaticalizó, lo que ha dado lugar a un doblete semántico.

Tómese este otro ejemplo: conuentiō y contiō. De la primera tenemos:

conuentiō, - -ōnis, $f$., asamblea del pueblo, reunión, junta \| in manum c., sumisión al poder militar ॥ convención, pacto II citación a juicio, acusación. (Segura-Munguía, 2003, p. 168)

Para la segunda, por su parte:

\begin{abstract}
contiō, - -ōnis, $f$., asamblea del pueblo [convocada y presidida por un magistrado y en la que no se vota]: contiōnem aduocāre, habēre, convocar, presidir una asamblea del pueblo; contiōnem dimittere, submouēre, disolver la asamblea; laudāre aliquem prō contiōne, elogiar a alguien ante la asamblea popular II asamblea militar II arenga; discurso [pronunciado en una asamblea]: contiōnēs habēre, pronunciar discursos políticos, arengas; contiōnem apud mīlitēs habuit, pronunció una arenga ante los soldados II [locuc.] in contiōnem prōdīre, adelantarse a hablar en la asamblea; in contiōnem ascendere, subir a la tribuna [de las arengas, para hablar al pueblo]. (Segura-Munguía, 2003, p. 165)
\end{abstract}

Es evidente que contiō es el resultado de una síncopa de la sílaba-uen-. Sus primeras acepciones coinciden con las de conuentiō, pero es patente que operó una especialización, producto del uso, en ciertos contextos. Es precisamente este empleo, aunado a principios de economía lingüística que se dio esta contracción y surgió el neologismo.

Así como ocurrió con opera y contiō muchas voces surgieron producto de fuerzas propias del latín vulgar, ya de orden fonético, ya psíquico. 
La asimilación y la disimilación son parte de estos complejos fenómenos lingüísticos que han dado lugar a palabras con doble grafía en latín. Su origen está asociado al habla, en este caso, de los latinos, quienes en su pronunciación incurrían en confusiones expresadas, posteriormente, en la escritura.

En numerosas ocasiones los estudiantes de latín encuentran en sus diccionarios indicaciones como las siguientes:

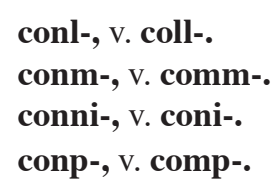

Este breve elenco de relaciones, típicas de todo diccionario de latín, ejemplifican claramente fenómenos como la asimilación, la simplificación y la disimilación. Tales referencias, las cuales responden a un principio de economía en los textos, testimonian la recurrente presencia de dos o más grafías para una misma palabra en latín.

Por ejemplo, colloquor es una forma verbal que deriva etimológicamente de la preposición cum y el verbo loquor, donde la nasal se ha asimilado a la - $l$ para facilitar la vocalización.

De nītor y esta misma preposición se obtiene el verbo cōnītor, hacer esfuerzos conjuntos o a la vez, en el que destaca la simplificación $n<n n$ ante la imposibilidad lingüística de pronunciar dos $n$ diferenciadas.

No es extraño encontrar en los textos clásicos, incluido Cicerón, palabras en las que la grafía responde ya a la etimología, ya a la forma modificada.

Véase a este tenor el siguiente pasaje de la Retórica a Herenio (atribuida por largo tiempo a Cicerón):

Dispositiō est ordō et distributiō rērum, quae dēmōnstat, quid quibus locīs sit conlocandum. (2010, 2, II, 3)

Conlocandum/collocandum es un doblete de entre muchos que se pueden encontrar en los clásicos.

En Fedro, por su parte, se encuentra el siguiente verso: uidē nē dolōne collum conpungam tibi $(1965,266$, III, 6,3). En este, se registra conpungam en lugar de compungam.

Tal y como se aprecia, todos estos procesos lingüísticos responden a requerimientos del habla, es decir, del latín vulgar, objeto aquí estudiado.

\section{Conclusiones}

A lo largo de la prolongada vida de la lengua latina, siempre existió una variante del latín vulgar, la cual no fue una expresión monolítica del latín, ya que estuvo sometida a numerosas y diversas vicisitudes de muy diversa índole.

Se ha podido mostrar cómo el propio latín vulgar contribuyó de alguna manera a la conformación de lo que conocemos como latín clásico en dos campos muy importantes: los neologismos y la morfología de las palabras.

De esta manera, se espera que la tensión que en no pocas ocasiones suele establecerse entre estos dos registros disminuya y se alcance una visión más rica y dinámica de su compleja realidad. 


\section{Bibliografía}

Autor desconocido. (2010). Retórica a Herenio. [Introducción, traducción y notas de Bulmaro Reyes Coria]. México, D. F.: Universidad Nacional Autónoma de México.

Campos-Vargas, H. (2010). El latín vulgar: origen del latín clásico. Revista Káñina. 34 (2), 127-136.

Herman, J. (2001). El latín vulgar. [Edición española reelaborada y ampliada con la colaboración de Carmen Arias Abellán]. Barcelona: Editorial Ariel.

Phaedrus et Babrius. (1965). Babrius and Phaedrus fables. (Trad. B.E. Perry). Michigan: Hardvard University Press.

Quirós-Rodríguez, M.A. (2000). El latín y las lenguas romances. San José: Editorial Universidad de Costa Rica.

Quirós-Rodríguez, M.A. (2003). Latín hablado, latín clásico. $1^{\text {a }}$ edición. Editorial Universidad de Costa Rica. San José.

Segura-Munguía, S. (2003). Nuevo diccionario etimológico Latín-Español y de las voces derivadas. Bilbao: Universidad de Deusto.

Valerio, C.C. (2012). Cármenes. Introducción, versión rítmica y notas de Rubén Bonifáz Nuño. ( $1^{\mathrm{a}}$ reimpresión en edición rústica). México, D. F.: Universidad Nacional Autónoma de México.

Väänänen, V. (1967). Introducción al latín vulgar. Madrid: Gráficas Cóndor. 
